\title{
1. Corporate rescue - the new orientation of insolvency law
}

\section{INTRODUCTION}

In the modern legal regime for corporate insolvency there are two basic routes which can be followed in dealing with a company that is failing: liquidation and corporate rescue. Both provide a collective way of settling the fate of the company when the claimants cannot resolve the company's financial troubles through private negotiations. Yet they provide two distinct paths to address the financial difficulties of a business. Liquidation serves the basic purpose of winding up an ailing company through an orderly collection and realisation of assets for the benefit of the claimants. The net value that is gathered through this collective debt collection process is then distributed among claimants according to a statutory system of priorities. On the other hand, corporate rescue procedures provide an alternative to the immediate liquidation of the ailing company, seeking to provide companies in financial difficulty with a period of respite in which compromises and rescue arrangements can be made. But, what exactly do we mean when we use the term 'corporate rescue'? What values and purposes does it serve? How can a rescue be achieved? What conceptual, legal and practical problems arise in relation to corporate rescue?

This introductory chapter will offer a brief overview of the above issues in order to provide the contextual background to the use of 'pre-packs' as a corporate rescue strategy. This chapter is divided into six sections. After these introductory remarks, sections 2 and 3 provide essential definitions for the purposes of this book. Section 4 reviews theories underpinning the goals of insolvency law and corporate rescue, examining how the various and competing goals that underlie the insolvency system could be effectively served. Section 5 considers different approaches to retaining the going-concern value in businesses that are in financial distress and the unique features of pre-pack restructuring. The last section reflects on the challenges in corporate rescue, and 
points out what causes controversy comes from in the case of the pre-pack rescue approach.

\section{THE CONCEPT OF CORPORATE RESCUE}

The term 'corporate rescue' is understood in very different ways by policy-makers, judges and scholars. These differences often stem from the divergent standpoints regarding the approaches and purposes of rescue actions in response to companies' financial troubles. First, corporate rescue can be premised on (contractually agreed) informal mechanisms as well as on formal collective legal proceedings. Professor Belcher defined the term 'corporate rescue' as 'a major intervention necessary to avert eventual failure of the company'. ${ }^{1}$ Such a broad definition encompasses any drastic remedial action to a company at a time of corporate crisis, including both the informal and formal strategic rescue responses. ${ }^{2}$ In contrast, a narrow definition of the term uses it to cover only the operation of legal proceedings, which offer facilitating mechanisms for rescuing financially distressed companies. Furthermore, the term may be defined differently as a way to reflect the various outcomes of rescue activities. Corporate rescue, or 'corporate reorganisation' in North American terminology, may be regarded as an alternative to immediate liquidation of the company, with the aim to prevent the death of the company. In the UK, the scope of rescue is wider, including both a turnaround of the company and alternatively preserving the core of a company's business. Underlining such differences is the distinction between 'company rescue' and 'business rescue'.

Company rescue works towards the restoration of a company in difficulty, which leads to the preservation of the legal entity itself so that the company can continue operations after reorganisation. In contrast, business rescue implies the termination of the old company, but the actual business and its activities will remain as a cohesive, productive unit under new ownership. This happens where a company is insolvent but successful steps are taken to retain the business as an operational enterprise, to sustain the employment of groups of workers and to ensure the survival of some economic activity. ${ }^{3}$ Company rescue often involves changes in the management of the company and is usually achieved through

\footnotetext{
A Belcher, Corporate Rescue (Sweet and Maxwell, London 1997), 12.

Ibid., 12.

V Finch, Corporate Insolvency Law: Perspectives and Principles (2nd edn, CUP, Cambridge 2009), 188.
} 
reorganising methods such as refinancing, debt composition or rescheduling, downsizing activities, and making redundant part of the workforce to offer temporary relief. ${ }^{4}$ Business rescue is commonly achieved through the sale of the company's assets and business as a going concern, which, as commonly believed, could generate more value than assets being sold in a piecemeal fashion.

For the purposes of this book, the term 'corporate rescue' will refer to collective strategic rescue proceedings under a legal framework designed to facilitate either the preservation of the distressed company itself or the rescue of its underlying business by transferring it to a new owner. It should be clarified that rescue outcomes can be achieved not only through rescue-oriented proceedings but also through a liquidation procedure. As mentioned earlier, the liquidation procedure is oriented to the winding-up of the company by ceasing its operations, realising its assets and paying off its debts and liabilities. ${ }^{5}$ In the process of realising its assets, a result that amounts to a rescue may be achieved where the company's assets are sold in the form of a complete takeover or a bulk sale of the assets, which involves the sale of the entire business, including goodwill and other intangibles. ${ }^{6}$ Nevertheless, despite the rescue outcomes, the liquidation procedure is not recognised as part of corporate rescue proceedings in the sense used here since its goal is different. The distinctive feature of a rescue procedure is that it is designed to capture the going-concern surplus in corporate restructurings and insolvency, in general. The going-concern surplus can be obtained if the business and assets are preserved as an operating unit, surviving either through a successful company turnaround or reorganisation, or through a goingconcern sale, where the whole or substantial business and assets of the ailing company are preserved.

4 J Armour, A Hsu, and A Walters, The Impact of the Enterprise Act 2002 on Realisations and Costs in Corporate Rescue Proceedings (2006) Report to The Insolvency Service <http://citeseerx.ist.psu.edu/viewdoc/download?doi= 10.1.1.96.6853\&rep=rep1\&type=pdf $>$ accessed 30 July 2015, 2.

5 G McCormack, Corporate Rescue Law: An Anglo-American Perspective (Edward Elgar, Cheltenham 2008), 3.

6 J Armour, 'The Law and Economics of Corporate Insolvency: A Review' (2001) ESRC Centre for Business Research, University of Cambridge, Working Paper No. 197 <http://www.econ.jku.at/members/Buchegger/files/ Juristen/armour_2001_corporate\%20insolvency.pdf> accessed 30 July 2015, 4. 


\section{THE SURPLUS OF GOING-CONCERN VALUE}

It is commonly acknowledged that the rationale of corporate rescue is to capture the surplus of going-concern value of the assets of the ailing company, in that the value of a company's business operations is likely to be far greater than the scrap value of its assets. ${ }^{7}$ As has been noted: '[w]e have a going-concern surplus (the thing the law of corporate reorganisations exists to preserve) only to the extent that there are assets that are worth more if located within an existing firm. If all the assets can be used as well elsewhere, the firm has no value as a going concern.' 8 The expression 'going-concern value' is contrasted with piecemeal liquidation value, which is referred to as the value realised when the parts of the business and assets are broken up and sold off separately. The goingconcern value could be measured by estimating the income stream that the assets would generate if they were kept together, taking into account the risk of reorganisation failure and comparing it to the amount that the assets would realise if they were sold off separately. ${ }^{9}$

But what are the sources of going-concern surplus that exceed their piecemeal liquidation value? In other words, where does the additional value come from? Traditional thinking places the source of goingconcern surplus in the intangibles associated with the running of the business, such as goodwill and intellectual property. It follows that salvaging a company's going-concern value can be achieved by holding together a 'bundle' of intangible assets (patents, accounts receivable, customer lists and orders, etc.) and employees, and outsourcing most manufacturing activities. Nevertheless, this assertion has been challenged in the wake of the tremendous change in fundamental forces at work in the economy, brought on especially by the decline of heavy industry, technological advances, easier access to capital and credit markets, globalisation and the birth of a service-based economy. The premise of the going-concern value in the traditional sense has also been questioned by the argument that if the intangible assets are the only source of the going-concern surplus, most failed companies may be said to have no

7 McCormack, Corporate Rescue Law: An Anglo-American Perspective, 3.

8 DG Baird and RK Rasmussen, 'The End of Bankruptcy' (2002) 55 Stanford Law Review 751, 758.

9 See DG Baird and TH Jackson, 'Corporate Reorganisation and the Treatment of Diverse Ownership Interests: A Comment of Adequate Protection of Secured Creditors in Bankruptcy' (1984) 51 University of Chicago Law Review 97, 109. See also TH Jackson, The Logic and Limits of Bankruptcy Law (Harvard University Press, Harvard 1986), 184. 
going-concern surplus, as their failure is usually due to their lack of valuable intangible assets, having neither a sound business strategy nor a good reputation. ${ }^{10}$

The basis of the modern economy has transformed from the traditional manufacturing activity to the information-based economy, in which the most valuable resource may be human capital and relationship networks. ${ }^{11}$ It is argued that going-concern value resides principally in various relationships 'among people, among assets, and between peoples[sic] and assets'. ${ }^{12}$ Costs incurred in creating most of these necessary relationships will inevitably be lost if the business is scattered to the wind through a piecemeal sale of assets, ${ }^{13}$ and starting a business from scratch is expensive and time consuming and entails a large degree of entrepreneurial risk. ${ }^{14}$ These points have been well made by the legal department of the International Monetary Fund:

in the modern economy, the degree to which an enterprise's value can be maximised through liquidation of its assets has been significantly reduced. In circumstances where the value of a company is increasingly based on technical know-how and goodwill rather than on its physical assets, preservation of the enterprise's human resources and business relations may be critical for creditors wishing to maximise the value of their claims. ${ }^{15}$

\section{DIVERSE THEORIES OF INSOLVENCY LAW AND THE GOALS OF CORPORATE RESCUE}

Although it has been commonly recognised that corporate rescue is concerned with how to capture and maximise the going-concern surplus of distressed companies and how to distribute it among corporate

10 See DG Baird and RK Rasmussen, 'Chapter 11 at Twilight' (2003) 56 Stanford Law Review 673, and Baird and Rasmussen, 'The End of Bankruptcy', 751.

11 McCormack, Corporate Rescue Law: An Anglo-American Perspective, 7.

12 L Lopucki, 'The Nature of the Bankrupt Firm: A Reply to Baird and Rasmussen's The End of Bankruptcy' (2003) 56 Stanford Law Review 645, 652.

13 McCormack, Corporate Rescue Law: An Anglo-American Perspective, $4-5$.

14 H Miller and S Waisman, 'Does Chapter 11 Reorganisation Remain a Viable Option for Distressed Businesses for the Twenty-First Century?' (2004) 78 American Bankruptcy Law Journal 153, 192-3.

15 Legal Department of International Monetary Fund, Orderly \& Effective Insolvency Procedures: Key Issues (1999) <http://www.imf.org/external/pubs/ft/ orderly/> accessed 30 July 2015. 
constituents, different standpoints have been taken on the ways and means of realising this maximisation and whose interests should be protected. In order to reflect these different points of view, it is important to understand the diverse normative theories and hypotheses about the appropriate objectives and purposes of corporate insolvency law.

The modern debate began in the US during the 1980s over the question whether insolvency law does - or should - seek only to maximise the returns to pay creditors of an insolvent company, or whether other goals do or should matter; such as preserving jobs, rehabilitating troubled companies and protecting the interests of local communities. ${ }^{16}$ Among the competing views on the goals or values that insolvency law should reflect, on one side, there is a 'market and assets' camp focusing on the assets of the debtor and value maximisation for creditors. On the opposite side is the 'enterprise and forum' camp, which argues that preserving an enterprise is to the benefit of many more interests than merely those of the owners and creditors, and the function of bankruptcy procedures is to establish a forum where all the interests which may be affected by the business failure can be heard. ${ }^{17}$

\section{The Creditors' Bargain Theory}

The creditors' bargain theory was advanced and developed by Professor Thomas Jackson with Douglas Baird and Robert Scott. ${ }^{18}$ The classical argument it propounded is that corporate insolvency law, at its core a collective debt collection mechanism, should be concerned only with the maximisation of creditors' returns and creditors' distribution questions. ${ }^{19}$

16 Armour, The Law and Economics of Corporate Insolvency: A Review, 8.

17 A Flessner, 'Philosophies of Business Bankruptcy Law: An International Overview' in JS Ziegel (ed) Current Developments in International and Comparative Corporate Insolvency Law (OUP, Oxford 1994), 13-24.

18 See TH Jackson, 'Bankruptcy, Non-Bankruptcy Entitlements, and the Creditors' Bargain' (1982) 91 Yale Law Journal 857; also Jackson, The Logic and Limits of Bankruptcy Law; DG Baird and TH Jackson, 'Bargaining After the Fall and the Contours of the Absolute Priority Rule' (1988) 55 University of Chicago Law Review 738; Baird and Jackson, 'Corporate Reorganizations and the Treatment of Diverse Ownership Interests: A Comment on Adequate Protection of Secured Creditors in Bankruptcy'; T Jackson and R Scott, 'An Essay on Bankruptcy Sharing and the Creditors' Bargain' (1989) 75 Virginia Law Review 155.

19 For the description of the common pool problem, see Jackson, The Logic and Limits of Bankruptcy Law, 11-12; and Baird and Jackson, 'Corporate 
First, it views insolvency law as a collectivised debt collection mechanism and as a response to the 'common pool' problem. ${ }^{20}$ To prevent the destruction of value caused by individual creditor actions against assets, interested persons need to act collectively. ${ }^{21}$ The collectivist compulsory system of insolvency law is justified on the grounds of a hypothetical bargain assumption that were company creditors free to agree on forms of enforcement of their claims on insolvency, they would agree to collectivist arrangements rather than procedures of individual action or partial collectivism. ${ }^{22}$

Second, the cornerstone of the creditors' bargain theory is the normative claim that pre-insolvent entitlements should not be impaired in the collective insolvency process. ${ }^{23}$ Through a hypothetical bargain that focuses on the key bankruptcy objective of maximising the welfare of the group through collectivisation, the creditors agree to act as a group under a regime replicating their non-bankruptcy collection rights. ${ }^{24}$ Bankruptcy law should change a substantive non-bankruptcy rule only when doing so preserves the value of assets for the group of investors holding rights in them. ${ }^{25}$ Third, the broad concerns regarding business failures and social welfare are not bankruptcy problems at all but 'that of the bulk of laws outside of bankruptcy'. ${ }^{26}$ As it is accepted here that bankruptcy law is primarily concerned with recognising non-bankruptcy entitlements and ensuring a deployment of assets that is in the interests of all those with rights to the assets under state law, it follows that the problems brought

Reorganizations and the Treatment of Diverse Ownership Interests: A Comment on Adequate Protection of Secured Creditors in Bankruptcy', 103-5.

20 Jackson, The Logic and Limits of Bankruptcy Law, 9-11.

21 Baird and Jackson, 'Corporate Reorganizations and the Treatment of Diverse Ownership Interests: A Comment on Adequate Protection of Secured Creditors in Bankruptcy', 106.

22 Jackson sees bankruptcy as 'a system designed to mirror the agreement one would expect the creditors to form among themselves were they to negotiate such an agreement from an ex ante position'. See T Jackson, 'Bankruptcy, Non-Bankruptcy Entitlements, and the Creditors' Bargain' (1982) 91 Yale Law Journal 857, 860.

23 Jackson and Scott, 'An Essay on Bankruptcy Sharing and the Creditors' Bargain', 159.

24 'A central premise underlying the creditors' bargain theory is that a system of state law entitlements (including priorities among secured and unsecured creditors) is already in place.' Ibid., 159.

25 Baird and Jackson, 'Corporate Reorganizations and the Treatment of Diverse Ownership Interests: A Comment on Adequate Protection of Secured Creditors in Bankruptcy', 100.

26 Ibid., 103. 
by business failures are not bankruptcy problems. Bankruptcy proceedings should not be the place to implement a policy that society does not enforce outside of bankruptcy and that is unrelated to the preservation of assets for the firm's investor group. ${ }^{27}$ It follows from the above arguments under this theory that the protection of the non-creditor interests of other victims of corporate misfortune, such as employees, managers, suppliers and the community at large ought not to be a concern of insolvency law. ${ }^{28}$

The creditor wealth maximisation argument has been highly influential and has been put into legislative effect in many jurisdictions. ${ }^{29}$ However, this normative theory has been subject to extensive criticism by a number of schools of thought. Major concerns have focused on challenging the claim that insolvency is simply a debt collection process for the benefit of creditors and that the only legitimate goal of insolvency law is creditor wealth maximisation. The creditor wealth approach considers only hypothetical contract creditors, which is only one group of victims suffering from the company's financial distress, and this, it has been said, fails to take account of the wide range of other stakeholders (for instance, employees, dependent suppliers, regular customers and the local community at large) that the corporate insolvency may have an impact on. ${ }^{30}$ It is criticised that the creditor wealth maximisation view focuses only on

27 Ibid., 102.

28 Jackson, The Logic and Limits of Bankruptcy Law, 25. See also Baird and Jackson, 'Corporate Reorganizations and the Treatment of Diverse Ownership Interests: A Comment on Adequate Protection of Secured Creditors in Bankruptcy', 103. It recognises these problems as general problems, not as bankruptcy problems. Therefore: 'Social reform should be brought about through a broad changes in the substantive law rather than through ad hoc modifications of rights in bankruptcy.'

29 Such as the German Insolvency Code of 1994. The English insolvency law also provides some support for this argument. The interests of creditors take primacy over the interests of all other groups when the company seems to be in financial distress. It can also be seen from the shift of the directors' fiduciary duty of loyalty to the creditors of the company in the 'twilight' period and the administrator's duty to act in the interests of creditors as a whole. See Finch, Corporate Insolvency Law: Perspectives and Principles, 29 and Armour, 'The Law and Economics of Corporate Insolvency: A Review'.

30 DR Korobkin, 'Contractarianism and the Normative Foundations of Bankruptcy Law' (1993) 71 Texas Law Review 541, 555. See also E Warren, 'Bankruptcy Policy' (1987) 54 University of Chicago Law Review 775, 787-8. 
economic value and is incapable of recognising non-economic value aspects, such as moral, political, social and personal considerations. ${ }^{31}$

Rejecting the view that bankruptcy law is merely a response to the problem of collecting debt, Professor Korobkin presents a value-based account which views bankruptcy law as 'a response to the many aspects of financial distress - moral, political, personal, social, and economic and, in particular, to the grievances of those who are affected by financial distress'. ${ }^{32}$ Because the participants' varied grievances typically reflect conflicting and fundamentally incommensurable values, bankruptcy law has a distinct function to provide a forum for an ongoing debate in which these diverse values can be expressed and sometimes recognised. ${ }^{33}$ Moreover, the idea that a troubled company constitutes a mere pool of assets is also challenged. It is claimed that the company is not purely a lifeless pool of assets but an enterprise with personality:

Unlike mere property, a corporation, whether in or out of bankruptcy, has potential. A corporation can continue as an enterprise: as an enterprise, it can change its personality and, perhaps more importantly, whether the corporation continues and how it changes its personality affects people in ways that are not only economic. ${ }^{34}$

Professor Elizabeth Warren has criticised the creditors' bargain theory for facilitating the externalisation of costs. She noted that many of the social costs incurred in the creation of a firm were borne by those parties who are not creditors and who have no formal rights to the assets of the business, such as employees, communities, suppliers, customers and others. When the firm failed, those parties were left with the costs as the parties with formal legal rights against the debtor never completely internalise the full costs of a business failure. ${ }^{35}$ Therefore it is argued that insolvency law should look beyond pre-insolvency rights and recognise the interests of parties who lack formal legal rights in the pre-insolvency

31 See DR Korobkin, 'Rehabilitating Values: A Jurisprudence of Bankruptcy' (1991) 91 Columbia Law Review 717, 762. Korobkin, 'Contractarianism and the Normative Foundations of Bankruptcy Law', 581. Korobkin pointed out that 'the problem of collecting debt is a complex one, implicating moral, political, personal, social, as well as economic values'.

32 See Korobkin, 'Rehabilitating Values: A Jurisprudence of Bankruptcy', 721.

Ibid., 721-2.

Ibid., 745.

35 E Warren, 'Bankruptcy Policy Making in an Imperfect World' (1993) 92 Michigan Law Review 336, 356. 
scenarios as the protection insolvency law gives to these parties is derivative in nature and limited in scope. ${ }^{36}$

\section{A Broad-based Contractarian Model}

In his later work, Professor Donald Korobkin offered an alternative contractarian model, insisting on his proposition that the main purpose of bankruptcy law is to exist as a distinct system that deals with the general problems of financial distress, and not to specifically address the problem of recovering debt. ${ }^{37}$ Instead of viewing insolvency law as the set of rules that contractual creditors would agree to from behind the veil of ignorance, ${ }^{38}$ Korobkin considered bankruptcy legislation to be 'the product of social exigency, moral conflict, and political compromise'. ${ }^{39} \mathrm{He}$ propounded a normative framework for bankruptcy law based on a hypothetical bargain struck by the representatives of all interests that might be affected by a company's decline. ${ }^{40}$ There should be some 'normative foundations' of bankruptcy law on which conflicting parties develop their arguments. The normative principles will prescribe limits on how bankruptcy law should alter the rights, authority and practical leverage of persons in financial distress, and offer a justified standpoint for evaluating which legal, political and personal advantages ought to be preserved and which ought to be modified. ${ }^{41}$

By constructing a hypothetical 'initial status quo' for the choice of the normative principles, Korobkin asserted that the parties would choose

\footnotetext{
36 Ibid.

37 See Korobkin, 'Contractarianism and the Normative Foundations of Bankruptcy Law'.

38 The 'veil of ignorance' is a position in which: 'no one knows his place in society, his class position or social status; nor does he know his fortune in the distribution of natural assets and abilities, his intelligence and strength, and the like. Nor, again, does anyone know his conception of the good, the particulars of his rational plan of life, or even the special features of his psychology such as his aversion to risk or liability to optimism or pessimism.' See Korobkin ibid., 564 referring to Rawls' famous concept, utilised as an important building block of his theory of justice. See further J Rawls, A Theory of Justice (Harvard University Press, Harvard 1971).

39 Korobkin, 'Contractarianism and the Normative Foundations of Bankruptcy Law', 543. 28.

40 McCormack, Corporate Rescue Law: An Anglo-American Perspective,

41 Korobkin, 'Contractarianism and the Normative Foundations of Bankruptcy Law’, 551.
} 
two principles to govern insolvencies: (1) the 'principle of inclusion' and (2) the 'principle of rational planning'.42 The principle of inclusion emphasises that all affected parties would be eligible to press their demands in the context of financial distress, although this does not speak to all parties whose particular demands should ultimately be recognised or denied. ${ }^{43}$ The 'principle of rational planning' has two essential ingredients: (1) the insolvency law must be broadly effective, promoting as many aims as possible; (2) when it is not possible to achieve all the aims, it must work to achieve the aims that are most important. ${ }^{44}$ On this model, the bargainers all know they may be affected by the insolvency, but no one knows if he will be: a debtor; an unsecured creditor whether contractual or involuntary; a secured creditor; an ordinary employee; a member of the community that is otherwise unconnected to the debtor company; or somebody in a different kind of relationship. ${ }^{45}$ Therefore, the bargainers would prefer a principle that is 'somehow capable of maximising their welfare whichever positions they happened to occupy in varying contexts' ${ }^{46}$ But if no principle can guarantee the best outcome for all parties under all circumstances, then 'as a matter of self-interest under conditions of radical uncertainty, they would want a principle that had the effect of mitigating, at least to some degree, the hardship experienced by persons in the worst-off positions'. ${ }^{47}$ Those in the worst-off position are 'relatively powerless in promoting their aims' and since they 'have the most to lose if their aims are frustrated', are the most vulnerable. ${ }^{48}$ Therefore, the principle of rational planning is to maximally satisfy the aims of parties as a whole by virtue of protecting the most vulnerable parties in the context of financial distress over those who are less vulnerable.

The contractarian approach has been subjected to extensive criticism. It has been said that ex ante hypothetical bargain theories of insolvency law are open to the objection that they amount to little more than an argument that thoughtful, interested, objective and neutral law makers would come

\footnotetext{
42 Ibid., 575-89.

43 Ibid., 575.

44 Ibid., 581.

45 McCormack, Corporate Rescue Law: An Anglo-American Perspective,

46 See Korobkin, 'Contractarianism and the Normative Foundations of Bankruptcy Law', 578.

47 Ibid., 579.

$48 \quad$ Ibid., 584.
} 28. 
to the proponent's conclusions about insolvency. ${ }^{49}$ By constructing a hypothetical original position in which the various players act in an economically rational manner according to a single set of criteria, the contractarian approach is unable to recognise the complex realities of business life and the many possible considerations the decision-makers may take into account in the matrix of circumstances. ${ }^{50}$ Furthermore, the value-based account does not in itself explain clearly important distributional issues, such as how to judge trade-offs between fairness or justice and wealth creation, and neither does it provide a working standard to measure this. It is further argued that the contractarian approach fails to explain how agreements can be reached behind the veil as to who in a potential insolvency is most vulnerable and thus should enjoy priority of protection over those occupying less threatened positions. ${ }^{51}$

\section{The Team Production Theory}

A team production theory of corporate reorganisation law has been recently developed by Professor Lynn LoPucki. ${ }^{52}$ It is based on the original team production theory of the corporation introduced by Margaret Blair and Lynn Stout in 1999,53 in which the interests of corporation are understood as 'a joint welfare function of all the individuals who make firm-specific investments and agree to participate in the extra-contractual, internal mediation process within the firm' ${ }^{54}$ The team membership may include: stockholders; company managers; other employees; suppliers; creditors; customers; local governments; regulatory agencies and others. ${ }^{55}$ In order to share all the costs and benefits of incorporation, and because of the impossibility of reaching that effect through direct contracts in some circumstances, team members

49 See McCormack, Corporate Rescue Law: An Anglo-American Perspective, 29-30 referring to CW Mooney 'A Normative Theory of Bankruptcy Law', whose comments were framed with particular reference to Korobkin's theory. 30.

50 McCormack, Corporate Rescue Law: An Anglo-American Perspective,

51 See Finch, Corporate Insolvency Law: Perspectives and Principles, 39-40.

52 LoPucki, 'A Team Production Theory of Bankruptcy Reorganisation' (2004) 557 Vanderbilt Law Review 741.

53 MM Blair and LA Stout, 'A Team Production Theory of Corporate Law'

(1999) 85 Virginia Law Review 247.

54 Ibid., 288.

749.

5 LoPucki, 'A Team Production Theory of Bankruptcy Reorganisation', 
can delegate an independent authority group - the board of directors - to divide profit and loss among them, based on each member's contributions to the team. ${ }^{56}$ Under the team production theory, corporate reorganisation is viewed not as a regulation imposed by government but instead as 'a contract term by which creditors and shareholders agree to subordinate their legal rights to the preservation of the going concern'. ${ }^{57}$ The preservation of the corporate entity is an independent value that partially accounts for the choice of reorganisation over liquidation. ${ }^{58}$

By leaving the board of directors in full control, while at the same time limiting creditors and shareholders to their bankruptcy entitlements, the team production contract has, in effect, granted the non-legally enforceable entitlements of team member priority over the legally enforceable claims of creditors and the interests of shareholders. ${ }^{59}$ Professor LoPucki asserts that this treatment is appropriate because honouring team production entitlements is efficient as those entitlements are payable under the team production contract and the team production contract is the bargain actually struck by team members. This is not only to reward past contributions, but also to incentivise future contribution to the team effort. ${ }^{60}$ The calculation of the benefits of reorganisation must also take into account distributions to all team members instead of only those to creditors and shareholders.

In a nutshell, the team production theory attempts to offer a justification of corporate reorganisation by adopting the new contractarian theory of the public corporation introduced by Professors Blair and Stout in 1999 to the bankruptcy reorganisation regime. Nevertheless, critical questions remain unresolved. The theory relies on an independent board of directors, acting as fiduciaries, to divide profit and loss among them based on the team members' respective contributions to the team. But it remains debatable whether the directors will do 'the right thing', given that the theory is based on a 'wholesale grant of unfettered power to directors'.61 It is asserted that directors would function less like disinterested trustees and more like representatives in a legislature who are expected to vigorously defend the interests of the particular constituents

56 Blair and Stout, 'A Team Production Theory of Corporate Law', 749-50.

57 LoPucki, 'A Team Production Theory of Bankruptcy Reorganisation', 743.

Ibid., 769.

Ibid., 758.

Ibid., 750.

$61 \quad$ Ibid., 778. 
who elect them. ${ }^{62}$ It is explicitly accepted that team members trust directors not because they think directors will do a good job, but because team members lack better alternatives. ${ }^{63}$

\section{The Multiple Values/Eclectic Approach}

Professor Elisabeth Warren considers that the creditors' bargain theory, as a single, unified theory of bankruptcy, is more of an intellectual view of bankruptcy than a complex one and runs a great risk of providing answers that, while quite sensible within confined, abstract schemes, will not work in a complex real-life corporate environment. ${ }^{64}$ She has offered a 'dirty, complex, elastic, interconnected view of bankruptcy' from which outcomes cannot be predicted, and nor can all the factors relevant to a policy decision be fully articulated. ${ }^{65}$ She explained what she has offered is 'a comprehensive statement about the various and competing goals that underlie the bankruptcy system' so as to provide useful assistance to the legislative and judicial decision-making. ${ }^{66}$

Warren describes bankruptcy as a collection system that determines: the value of a failing business; how to distribute that value among parties whom the failure affects; and the extent to which affected parties can externalise the costs of failure to others who did not deal with the debtor. This system, according to her, is aimed toward four principal goals:

(1) to enhance the value of the failing debtor; (2) to distribute value according to multiple normative principles; (3) to internalise the costs of the business failure to the parties dealing with the debtor; and (4) to create reliance on private monitoring. ${ }^{67}$

62 See Blair and Stout, 'A Team Production Theory of Corporate Law', footnote 136 at $\mathrm{p} 302$.

63 LoPucki, 'A Team Production Theory of Bankruptcy Reorganisation', 778.

64 Warren, 'Bankruptcy Policy Making in an Imperfect World', 813.

65 Ibid., 811.

66 'I have not offered a single-rationale policy that compels solutions in a particular case. I have not given any answers to specific statutory issues. I have only identified normative considerations that may drive legislative and judicial decisions.' Ibid., 795-6.

67 Warren, 'Bankruptcy Policy Making in an Imperfect World', 343-4. 
Unlike in the creditors' bargain theory where pre-insolvency entitlements should never be impaired to accomplish purely distributional goals, ${ }^{68}$ Warren asserts bankruptcy law can alter the interested parties' nonbankruptcy rights because bankruptcy and non-bankruptcy rights laws deal with different kinds of default. Non-bankruptcy law provides a collection scheme that copes with the single default where only one creditor complains about repayment. On the other hand, the bankruptcy collection scheme concentrates on the debtor's widespread default and the collapse of every creditor's prospects for repayment. ${ }^{69}$ The policy issues involved in the two scenarios present critical differences and thus different distributive schemes ought to be adopted. ${ }^{70}$

Warren listed a series of distributive rationales of bankruptcy law, such as favouring creditors but also pointed out that the distributive goals may conflict with each other. She asserted that it is difficult or even impossible to provide a consistent answer to questions such as how to reallocate the resources and how to solve the conflict between the different distributive goals.

With regard to the question of whose interests bankruptcy should serve, Professor Warren views bankruptcy as 'an attempt to reckon with a debtor's multiple defaults and to distribute the consequences among a number of different actors' ${ }^{71}$ Although bankruptcy encompasses a number of competing and sometimes conflicting values in this distribution, no one value, she asserted, should dominate so that bankruptcy policy can be a composite of factors that offers a better answer to the question "how shall the losses be distributed?'72 In her view, however, the insolvency regime only protects the interests of parties without formal legal rights in an indirect fashion, largely through provisions that permit businesses to reorganise instead of being shut down by a few anxious creditors. ${ }^{73}$

68 Jackson and Scott, 'An Essay on Bankruptcy Sharing and the Creditors' Bargain', 159.

69 Warren noticed that there are: 'two prototypes of default: first, the single default where only one creditor complains about repayment and the remaining creditors are evidently (even if only temporarily) content with their repayment prospects; and second, the debtor's widespread default and collapse in which every creditors' prospects for payment are sharply diminished.' See Warren, 'Bankruptcy Policy Making in an Imperfect World', 781.

70 Ibid., 782.

71 Ibid., 777.

72 Ibid.

73 Warren, 'Bankruptcy Policy Making in an Imperfect World', 355-6. 


\section{The Explicit Values Approach to Insolvency Law}

The aforementioned debate is primarily American. Similar debates on the objectives of corporate insolvency and the values of corporate rescue have also taken place in the UK. UK bankruptcy legislation has been rather creditor-oriented with an unforgiving attitude toward unpaid debt and credit. A liquidation culture prevailed in England until 1986, when deep recessions caused Parliament to reassess this position. ${ }^{74}$ In the Cork Report ${ }^{75}$ which was published in 1982, the Review Committee suggested that the aims of a good modern insolvency law should include those that:

(i) recognise the effects of insolvency are not limited to the private interests of the insolvent and his creditors, but that other interests of society or other groups in society are vitally affected by the insolvency and its outcome, and to ensure that these public interests are recognised and safeguarded;

(j) provide means for the preservation of viable commercial enterprises capable of making a useful contribution to the economic life of the country; ${ }^{76}$

It emphasised the social and personal detriment caused by shutdowns and wholesale redundancy 77 and the benefits to the country's economic life of preserving viable commercial enterprises, because corporate failure was usually accompanied by wider repercussions falling not only upon intimately connected parties such as directors, shareholders and employees, but also on other interests, such as suppliers. ${ }^{78}$

74 PR Wood, Principles of International Insolvency (2nd edn, Sweet and Maxwell 2007), 175.

75 Kenneth Cork and Insolvency Law Review Committee, Insolvency Law and Practice: Report of the Review Committee (Cmnd 8558, 1982). The Cork Committee, the chairman of which was the late Sir Kenneth Cork, was appointed in 1977 with wide-ranging terms of reference covering corporate and individual insolvency. Its report led to a government White Paper in 1984 - A Revised Framework for Insolvency Law (Cmnd 9175, 1984), setting out an intention to implement the bulk, but not all, of the Committee's recommendations. This eventually led to the Insolvency Act 1986.

76 Cork and Committee, Insolvency Law and Practice: Report of the Review Committee, 54-5. There were (a) to (1) aspects contained in the aims of a good modern insolvency law.

77 IF Fletcher, 'UK Corporate Rescue: Recent Developments - Changes to Administrative Receivership, Administration, and Company Voluntary Arrangements - the Insolvency Act 2000, the White Paper 2001, and the Enterprise Act 2002' (2004) 5 European Business Organization Law Review 119, 122.

78 Cork and Committee, Insolvency Law and Practice: Report of the Review Committee, 56. 
Professor Sir Roy Goode also suggests that corporate insolvency law should have four overriding objectives: (1) to rescue the debtor company where this is practicable; (2) to maximise the return to creditors as a whole where the company itself cannot be saved; (3) to establish a fair and equitable system for the ranking of claims and the distribution of assets among creditors, involving a limited redistribution of rights; and (4) to provide a mechanism by which the causes of failure can be identified and to disqualify those guilty of mismanagement by depriving them of their right to be involved in the management of other companies. ${ }^{79}$ Nevertheless, given that the role of insolvency law is "not to affect pre-bankruptcy the substance of entitlements but rather to organise a collective regime designed to ensure the preservation of those entitlements to the maximum extent possible', according to Professor Goode, it is only to this extent that the rehabilitation of an insolvent business is a legitimate function of corporate insolvency law. ${ }^{80}$

Professor Finch also believes that the key tasks of corporate insolvency law among other things should include: (1) facilitating the recovery of companies in times of financial crisis and stimulating the rehabilitation of insolvent companies and businesses as going concerns; (2) balancing the interests of different groupings and protecting the interests of the public and of employees in the face of financial failures or management malpractices; and (3) dissolving companies when necessary. ${ }^{81}$ In looking for the appropriate measure of insolvency law, more specifically, with regard to the objectives and their trade-off against each other associated with the openness concerning the objectives of corporate insolvency law, Finch borrows from Gerald Frug's well-known analysis of the strategies for attempting to legitimate corporate and bureaucratic power, and offers the so-called explicit values approach to measuring insolvency law. ${ }^{82}$ The explicit values approach 'takes on board the public and private, the procedural and substantive and the contractarian and democratic dimensions of insolvency'. ${ }^{83}$ She advocates that the legitimacy of the processes and principles of insolvency law can be tested by reference to four benchmarks, namely efficiency, expertise, accountability and fairness: (1) 'Efficiency' looks to securing democratically mandated ends at lowest cost; (2) 'Expertise' refers to the allocation of decision and policy

79 See R Goode, Principles of Corporate Insolvency Law (3rd edn, Sweet and Maxwell 2005), 39.

80 Ibid., 39.

81 Finch, Corporate Insolvency Law: Perspectives and Principles, 27.

82 Ibid., 64.

83 Ibid. 
functions to properly competent persons; (3) 'Accountability' looks to the control of insolvency participants by democratic bodies or courts or through the openness of processes and their amenability to representations; and (4) 'Fairness' considers issues of justice and propensities to respect the interests of affected parties by allowing such parties access to, and respect within, decision and policy processes. ${ }^{84}$

Nevertheless, in cases where the four values themselves have conflicts, Professor Finch's explicit values approach did not provide any further standards for determining preferences among them in the details. There is no clear answer on whether particular trade-offs between them are desirable or not. It is suggested that the merits of particular trade-offs may only be argued for in particular contexts and cannot be preordained according to set rules. ${ }^{85}$ Mokal has argued that Finch's understanding of the 'benchmark' concepts lacks consistency and that she is unable to provide a satisfactory account of their relationship inter se. According to him, 'expertise' and 'accountability' have no separate standing of their own, and should be absorbed within 'efficiency'. ${ }^{86}$ Fairness and efficiency cannot be traded off against each other, as efficiency in itself does not provide a goal that any area of the law should aim at. The failure to distinguish between the diverse nature of her otherwise well-argued benchmarks considerably weakens Finch's approach. ${ }^{87}$

\section{Summary of Findings}

This section reviewed the diverse normative theories and hypotheses about the appropriate objectives and purposes of corporate insolvency law. The creditor wealth maximisation argument promoted by the classical creditors' bargain theory has been widely criticised for its failing to take account of the wide range of stakeholders beyond a company's contract creditors that the corporate insolvency may have an impact on. Different standpoints have been taken on the goals of corporate insolvency law and whose interests should be protected. However, there is no consensus as to how various and competing goals that underlie the insolvency system should be prioritised and served, nor is there a working standard to determine preferences among them. As a result,

\footnotetext{
84 Ibid., 56.

85 Ibid., 65.

86 RJ Mokal, 'On Fairness and Efficiency' (2003) 66 Modern Law Review

87 Ibid.
} 452. 
critical questions, such as how to judge if trade-offs between different goals are desirable or not, remain unresolved.

\section{APPROACHES TO RESCUE}

With the rise in insolvency activity that was seen in the past recessions and the growing popularity of corporate rescues, a variety of rescue mechanisms have been developed within and outside insolvency law, generally falling into two categories: informal and formal rescue strategies. Informal rescues, also referred to as 'private restructurings' or 'workouts', ${ }^{8}$ are a non-judicial process through which a distressed company and its significant creditors ${ }^{89}$ attempt to reach an agreement to restructure and adjust the company's debt obligations without court intervention. Formal rescues, on the other hand, involve the use of legal procedures designed under insolvency legislation where the compromises and arrangements for restructuring are made under the supervision of the court or a formal legal structure.

\section{Informal Rescues}

Informal rescues are contractually based in nature and in themselves do not demand any sort of statutory intervention. A general advantage of private workouts is that they provide the debtor company and its creditors with a more flexible environment in which to negotiate the resolution of a company's financial difficulties than under insolvency procedures. Publicity concerning corporate failures is likely to be minimal, thus avoiding significant jeopardy to the goodwill and reputation of the company by the negative reactions of customers and the market. The private route allows the sale of the business to be completed in good time and with a low level of disruption from publicity, both of which are essential to preserve the value of the business. In formal insolvency procedures, the complex legal institutional constraints are likely to

88 Workout was defined as 'borrower's efforts to negotiate with its lenders for a restructuring of its debts outside of bankruptcy or other court proceedings'. MS Kirschner et al., 'Prepackaged Bankruptcy Plans: The Deleveraging Tool of the '90s in the Wake of Old and Tax Concerns' (1991) 21 Seton Hall Law Review 643 , at note 7 .

89 For instance, financial creditors such as banks, or major trade creditors and bondholders. 
produce more prolonged and often hostile litigation, which can have a significantly negative impact on the realisable value of the company's business.

Furthermore, the contractual basis of informal rescue action also means that the terms of restructuring can be easily altered and adjusted during negotiations in a way that formal procedures do not allow without a valid approval mechanism. ${ }^{90}$ Private workouts are commonly negotiated between a small group of leaders and the debtor out of the public eye. In addition, cooperation among a number of major creditors involved in a negotiation can be more readily achieved than aligning the diverse incentives of all conflicting claimholder classes as attempted under the insolvency procedures.

While noting the merits, the demerits of informal rescues are also obvious. A fundamental difficulty for the contract-based mechanism is the need to secure a consensus; usually the agreement of all parties whose rights are affected. Informal rescues are based on the contractual variation of existing rights by way of compromise, waiver or deferment of debts or alteration of priorities. They can only bind parties to the contract, therefore any dissenting creditors have the power to halt informal rescues by triggering formal insolvency procedures. This renders the informal rescue a fragile device which is dependent on a high degree of cooperation among a disparate range of parties. ${ }^{91}$ Another concern with the informal approach is its potential to prejudice the interests of less well-placed creditors, for there may be an absence of investigative powers and a lack of inquiry into the role the directors played in bringing a company to the brink of disaster. ${ }^{92}$

The 'London Approach', developed in the 1970s and designed to secure the cooperation of financial support for companies with liquidity problems, ${ }^{93}$ has been successful in resolving financial distress with large UK companies, especially for the large multi-bank financed companies. ${ }^{94}$ The British Bankers Association defined the 'London Approach' as 'a non statutory and informal framework introduced with the support of the Bank of England for dealing with temporary support operations mounted

90 Finch, Corporate Insolvency Law: Perspectives and Principles, 208.

91 D Brown, Corporate Rescue: Insolvency Law in Practice (Wiley Series in Commercial Law, J Wiley, New York 1996), 10. Finch, Corporate Insolvency Law: Perspectives and Principles, 209-10.

92 Finch, Corporate Insolvency Law: Perspectives and Principles, 209.

93 Goode, Principles of Corporate Insolvency Law, para.10-04.

94 Ibid., para.10-135. 
by banks and other lenders to a company or group in financial difficulties, pending a possible restructuring'. ${ }^{95}$ The rescue work is organised on a contractual basis, through which the potentially conflicting problems of company creditors are resolved through voluntary cooperation and coordination between the participating parties ${ }^{96}$ without having to resort to statutory backing. ${ }^{97}$

The process generally involves four phases. At the initial stage of the process, the participating parties should agree among themselves to an informal 'standstill', which typically last for several months and is sufficient to prevent all relevant creditors from taking any steps to enforce their claims against the debtor company. Secondly, a team of accountants appointed by the banks will investigate the company's financial condition and produce an independent review of the company's economic viability and long-term prospects. ${ }^{98}$ Their conclusion will be acted on by a collective decision-making process in which the main creditors work together to reach a joint view on what should be done with the company. ${ }^{99}$ Thirdly, to promote cooperation among the relevant creditors, a lead bank, typically the bank with a floating charge over the company's assets, is normally designated to organise the gathering and distribution of the information relevant to the rescue, negotiate with the other banks and coordinate their dealings with the distressed company. ${ }^{100}$ And finally, where negotiations are successful, an agreed business plan for the company is put into effect and is monitored. ${ }^{101}$ One or more committees representative of the main creditor classes will normally be

95 British Bankers' Association, 'London Approach' (16/02/2004) previously available at <http://www.bba.org.uk/bba/jsp/polopoly.jsp?d=130\&a=2281> accessed 9 November 2007.

96 Particularly the banks and other financial institution creditors.

97 Goode, Principles of Corporate Insolvency Law, para.10-135.

98 INSOL International, 'Statement of Principles for a Global Approach to Multi-Creditor Workouts' (Report) (2000), 2-3. And Goode, Principles of Corporate Insolvency Law, para.10-135.

99 One of the crucial tasks is to safeguard a sound information flow, including information-gathering and dissemination, among the participating parties so that the action taken is coordinated in a cooperative manner.

100 Creditor committees reduce information asymmetries that would endanger trust and cooperation between creditors and the debtor. See also P Brierley and G Vilieghe, 'Corporate Workouts, the London Approach and Financial Stability' (1999) 7 Financial Stability Review 168, 174; Finch, Corporate Insolvency Law: Perspectives and Principles, 221.

101 Finch, Corporate Insolvency Law: Perspectives and Principles, 220. 
established to assist the lead bank's coordination work and more importantly, to act as a provisional sounding board towards the evaluation of proposals for corporate debt restructuring and then the negotiation and implementation of the restructuring plan. ${ }^{102}$

The relative informality provided by the London Approach allows security interests to be adjusted, a process that may prove far less complex and expensive than receivership where a number of banks are involved. ${ }^{103}$ The approach relies on consensus, persuasion and banking collegiality in order to reconcile the interests of different creditors to a company in difficulty. ${ }^{104}$ Like general private restructuring agreements, rescue attempts in the London Approach typically involve creditors compromising existing rights and priority through debt-equity swaps; and postponing the date for repayments or reducing the interest rate on corporate debt, or parts of it, often accompanied by management changes, asset sales and securing new finance and new or increased director guarantees. In this context, the banks may agree to provide new funding, especially where fresh loans and attendant liquidity are necessary for the debtor's continued survival. Such additional funding is normally accorded priority over existing loans requisite creditors. ${ }^{105}$

It has been questioned how far the lead bank can, or has the standing to, intervene in the absence of regulatory powers. ${ }^{106}$ The operation of such voluntary collective action depends heavily on the lead lender discharging their coordination role effectively, as well as intensive

102 J Armour and SF Deakin, 'Norms in Private Insolvency Procedures: The 'London Approach' to the Resolution of Financial Distress' (2000) ESRC Centre for Business Research, University of Cambridge, Working Paper No. 173 $<$ http://core.ac.uk/download/pdf/7151360.pdf> accessed 30 July 2015, 38-9. Such committees are often advised and assisted by professional advisers for better commercial decision-making.

103 Finch, Corporate Insolvency Law: Perspectives and Principles, 219.

104 Ibid., 219-20.

105 The traditional domination of bank debt in financing large UK debtors is identified as one of the fundamental backgrounds of the prevalence of the London Approach. See further Armour and Deakin, 'Norms in Private Insolvency Procedures: The 'London Approach' to the Resolution of Financial Distress', 38.

106 Brown, Corporate Rescue: Insolvency Law in Practice, para.1.31. It becomes even more difficult for banks to coordinate given the increasing complexity of financial structures where hedge funds and private equity groups grew explosively in power and influence in recent years. This dramatically reduces the ability of the banks to pressure such parties into agreeing a rescue plan. See further V Finch, 'The Dynamics of Insolvency Law: Three Models of Reform', (2009) 3 Law and Financial Markets Review, 438. 
cooperation among the disparate range of interested parties. It has been argued that the main difficulty of the London Approach is the lack of any formal moratorium and the need for unanimity of support from relevant creditors. ${ }^{107}$ In addition, it is pointed out that, while this framework seems successful in large multi-bank corporate rescues, it might be less appropriate for the bulk of companies in distress where there may be only one bank and many non-financial institution creditors. ${ }^{108}$ Moreover, corporate financing practice has developed dramatically and therefore the marketplace in which the London Approach was developed has changed dramatically. ${ }^{109}$ Professor Finch has summarised the difficulties facing the London Approach as follows:

[m]odes of financing are becoming more fragmented and creditors' coordination is proving more difficult as bank creditors are joined by bond holders, secondary debt traders, joint venture partners, special creditor and supplier groups and intermediate investors. The globalisation of financial markets and the emergence of markets for distressed corporate debt also put strains on the London Approach. ${ }^{110}$

\section{Formal Rescues}

The statutory rescue procedures respond to the inherent and severe coordination problems and the holdout risks associated with the informal route. Essentially they offer a collective way in which all the affected parties are participating equally and treated according to the size and seniority of their credits. A formal procedure, such as Chapter 11 of the US Bankruptcy Code or the UK Administration, normally involve a moratorium on the enforcement of a wide range of creditors' rights and so creates a more sustainable space within which a rescue can be organised. ${ }^{111}$ Insolvency legislation also provides various mechanisms

107 Finch, Corporate Insolvency Law: Perspectives and Principles, 223.

108 Brown, Corporate Rescue: Insolvency Law in Practice, para.1.31. The complexity of the company's capital structure and the heterogeneity of the financial claims could generate severe holdout problems.

109 Armour and Deakin, 'Norms in Private Insolvency Procedures: The 'London Approach' to the Resolution of Financial Distress', 31-3.

110 V Finch, 'The Recasting of Insolvency Law' (2005) 68 Modern Law Review 713, 727. The sheer involvement of a greater number and diversity of players is likely to mitigate against the rapid, informed and cheap negotiation of rescues by a stable group of parties. See further Finch, Corporate Insolvency Law: Perspectives and Principles, 225.

111 Ibid., 210. 
whereby compromises and arrangements can be made under the supervision of the court or a formal legal structure, one objective of which is to ensure that minority dissenters are eventually bound. ${ }^{112}$

In the UK, corporate rescue procedures were first introduced through the administration order procedure and company voluntary arrangements (CVA) in the Insolvency Act 1985 and were re-enacted in the Insolvency Act 1986 (IA 1986), as recommended by the Cork Committee Report on Insolvency Law and Practice. The original administration model was not a complete rescue procedure, and its main effect was to impose a moratorium on the enforcement of creditors' claims. The Enterprise Act 2002 (EA 2002) introduced a streamlined administration model to replace the original procedure. Under the new regime, the administration may function either as a gateway to winding up, a CVA or a scheme of arrangements, or as a stand-alone procedure, which may lead directly to dissolution. The administrator is required to first consider rescuing the company as a going concern, unless in the administrator's view, that is not reasonably practical and/or it is not in the interests of creditors as a whole.

American Chapter 11, commonly referred to as 'reorganisation', aims at promoting the economically viable company to recovery and maintaining the business as a going concern. ${ }^{113}$ By granting an automatic stay to prevent creditors from collecting their claims or enforcing their liens, incumbent management is allowed to retain control of the company and is granted the exclusive right to propose a plan of reorganisation within 120 days after the Chapter 11 filing date. ${ }^{114}$

112 For instance, a creditors' meeting will be convened within a practically reasonable period; the reorganisation plan needs to be accepted by the majority of the allowed claims. Under English administration procedure, the administrator's proposals are passed when support is obtained from a majority in value of those present and voting creditors, either in person or by proxy. In the US, claims and interests are dealt with by classes, specifying unimpaired and impaired classes. A plan is deemed to be accepted when at least two-thirds of votes and more than one-half in number of allowed claims of each voting class of creditors, and two-thirds in amount of the shares for a class of equity interests, have accepted it.

113 It is said that the motive for introducing the Chapter 11 procedure was to increase the possibility that the company would emerge as a going concern from the reorganisation process. See J Franks and W Torous, 'Lessons from a Comparison of US and UK Insolvency Codes' (1992) 8 Oxford Review of Economic Policy 70, 75.

114 The court may grant extension of this exclusive period up to 18 months after the petition date. Plan negotiations typically are conducted primarily 
Both countries take a view that corporate rescues can be justified by the fact that assets used by a going concern company are more valuable than if the company was liquidated piecemeal, but the legal rescue procedures in the two jurisdictions are very different in terms of orientation and institutional arrangements. For an administration procedure, the rescue of the ailing company or the whole or part of its undertaking as a going concern is preferred, but it is not an overriding objective. The decision on which statutory purpose should be pursued is made by an outside insolvency practitioner who acts as the administrator. In contrast, the overriding objective of a Chapter 11 case, at least in theory, is the formulation and confirmation of a reorganisation plan agreed between creditors and shareholders. As already mentioned, incumbent management may remain in office and run the business as usual during the reorganisation process and are in charge of proposing a reorganisation plan. ${ }^{115}$

Accordingly, statutory rescue procedures are designed as a collective and inclusive rescue process under which all the parties-in-interests are equally participating and treated according to the size and seniority of their credits. In order to provide adequate protection for various groups of creditors, as well as checks and balances on the conflicting incentives among different stakeholders, the legal proceedings often involve complicated documentary accountability requirements and rounds of negotiations to conclude the approval of the rescue plan. This renders the formal approach a complex proceeding that is lengthy and costly, often eventually leading to unnecessary or premature corporate liquidations. The wider economic disruption generated gives claimholders the incentive to look for alternative restructuring strategies.

between the debtor and one or more official committees appointed shortly after the filing of debtor's bankruptcy petition, although any party in interest may seek to participate in negotiations. Once the debtor reaches agreement with its major constituencies on a plan that appears to have the necessary support to be confirmed, the plan will be filed with the bankruptcy court. See MD Plevin et al., 'Pre-Packaged Asbestos Bankruptcies: A Flawed Solution' (2008) 44 South Texas Law Review 883, 886.

115 Though the existing management can run the business in the ordinary way, court approval will be required for substantial asset sales, section 361 of the US Bankruptcy Code. For the relative merits of the US DIP model and the British PIP model, see D Hahn, 'Concentrated Ownership and Control of Corporate Reorganisations' (2004) 4 Journal of Corporate Law Studies 117; V Finch, 'Control and Co-ordination in Corporate Rescue' (2005) 25 Legal Studies 374. 


\section{Pre-pack: A Combined Form of Rescue Strategy}

The 'pre-pack' process is commonly seen as a hybrid form of corporate rescue combining the advantages of private restructuring with some of the properties of the formal procedure. Pre-packaged bankruptcies were first introduced in US insolvency practice. They provided a feasible option for financially distressed companies, which allowed them to avoid the significant expense and relatively complicated negotiation process under traditional US Chapter 11 proceedings. A 'pre-packaged' Chapter 11 describes the procedure of devising a plan of reorganisation and soliciting acceptance of such a plan prior to the commencement of a bankruptcy case. ${ }^{116}$ By doing so, an agreement is often drawn up as means of finding a compromise solution to satisfy the claims of large financial creditors. The claims of other creditors (particularly ordinary employees and trade creditors) may be left unimpaired to be paid in full under the restructuring plan. ${ }^{117}$ By leaving them unimpaired, the company avoids negotiating with a diverse and potentially most fractious creditor group thereby avoiding a serious holdout problem.

The holdout problem can be further minimised by filing for protection under a formal procedure, ${ }^{118}$ which has the legal power to bind dissenting creditors to the restructuring terms accepted by the majority of voting creditors, ${ }^{119}$ that is, two-thirds in amount and more than one-half in number of those voting. This can greatly reduce the time spent in bankruptcy, because the principal remaining tasks are the approval of the disclosure statement and confirmation of the plan by the court. ${ }^{120}$

116 Kirschner et al., 'Prepackaged Bankruptcy Plans: The Deleveraging Tool of the '90s in the Wake of Old and Tax Concerns', footnote 8 at p 644. In contrast to pre-packaged cases, there are also pre-negotiated cases, where some debtors negotiated the terms of their representatives prior to bankruptcy, but did not solicit usable votes prior to filing or did not solicit them from all impaired creditor classes. See T Eisenberg and LM LoPucki, 'Shopping for Judges: An Empirical Analysis of Venue Choice in Large Chapter 11 Reorganizations' (1999) 84 Cornell Law Review 967, 976.

117 TJ Salerno and CD Hansen, 'A Prepackaged Bankruptcy Strategy’ (1991) 12 Journal of Business Strategy 36.

118 Such as the UK administration procedure or the US Chapter 11 reorganisation.

119 KA Mayr, 'Enforcing Prepackaged Restructurings of Foreign Debtors under the U.S. Bankruptcy Code' (2006) 14 American Bankruptcy Institute Law Review 469, 497.

120 E Tashjian et al., 'Prepacks: An Empirical Analysis of Prepackaged Bankruptcies' (1996) 40 Journal of Financial Economics 135, 138. 
Similarly on the UK insolvency scene, there has been a considerable increase in the number of pre-packs in recent years. ${ }^{121}$ The percentage of administrations going through a pre-pack procedure has increased from approximately 25 per cent in 2011 to 29 per cent in $2012 .{ }^{122}$ Although the pre-pack strategy can be traced to other forms of insolvency proceedings such as liquidation and administrative receivership, there is a growing trend of utilising the administration procedure to implement a pre-agreed arrangement, especially after the increase in the use of administration by the EA 2002. A pre-pack administration therefore refers to the situation where arrangements for the sale of an insolvent business have been negotiated with prospective purchasers and agreed by the major creditors ${ }^{123}$ prior to the commencement of the administration procedure, with the sale being completed almost immediately after the appointment of an administrator.

The popularity of pre-pack restructuring in the UK and the US has been recognised by other jurisdictions in Europe and these are countries starting to introduce their own versions of pre-pack procedures, such as the Accelerated Financial Safeguard procedure (Procédure de Sauvegarde Financière Accélérée) in France ${ }^{124}$ and the new Protective Shield Proceedings (Schutzschirmverfahren) in Germany. ${ }^{125}$ Despite the gradual

121 Frisby's research samples of administration and receivership cases between September 2001 and September 2004 showed that there were 222 administration cases and 118 pre-packaged administration samples. Of the 118 administration pre-packs, 40 cases (33.9 per cent) were pre-Enterprise Act 2002 and 78 (66.1 per cent) were post-Enterprise Act 2002 cases. S Frisby, 'A Preliminary Analysis of Pre-Packaged Administrations' (Report) (R3: The Association of Business Recovery Professionals 2007), 15.

122 The Insolvency Service, 2012 Annual Review of Insolvency Practitioner Regulation (June 2013), 4.

123 This study uses the expression 'major creditors' as shorthand for the parties that could exert some degree of influence on the disposal process, including the senior secured bank creditors, significant trade creditors or bondholders.

124 The 'accelerated financial safeguard procedure' was created by the Banking and financial regulation law as of 22 October 2010, Loi de Régulation Bancaire et Financière, No. 2010-1249, JORF No. 0247, 23 October 2010 (Articles 57 and 58) and was codified in Article L.628-1 and L.628-7 of French Commercial Code.

125 The 'Protective Shield Proceedings' was introduced by the 'Act for the Further Facilitation of the Reorganization of Companies' (Gesetz zur weiteren Erleichterung der Sanierung von Unternehmen) enacted on 7 December 2011 and now is contained in Section 270b of the German Insolvency Code. 
recognition of the efficacy and efficiency of pre-pack practice in maximising the going-concern value of distressed businesses, the rescueoriented rules offered in different jurisdictions differ as to how far they can go in seeking to promote a more cooperative and risk-taking attitude among different parties from their respective standpoints. The differences in their institutional arrangements governing insolvency and corporate rescue reflect the differences in their culture, economic environment and political constraints.

\section{MODERN CORPORATE RESCUE CHALLENGES}

As explained earlier, corporate rescues are very different in orientation from many aspects of the liquidation process. Liquidation is commonly viewed as essentially involving foreclosure and a piecemeal sale of the business's assets, while the heart of a rescue process is seen as involving the continuation of the business. Rather than relatively static distribution proceedings in a strict order of priority, corporate rescues are more of a negotiating and thus bargaining proceedings focusing on ongoing commercial viability. They are accompanied by the uncertainty of the valuation on the financially distressed company. ${ }^{126}$

Theoretically, the rescue process is all about preserving the so-called going concern surplus in those businesses that are financially distressed but still economically viable, and identifying and liquidating those economically distressed ones in a timely manner. However, it is empirically difficult to distinguish between financial and economic distress. It is often not obvious whether a troubled company with financial difficulty is still economically viable or not and the judgement varies with different parties due to their possession of information about the company and their private interests. Furthermore, the process is accompanied by significant uncertainty with regard to what the value of the company turns out to be.

The future prospects for the turnaround of the company may well depend on: the severity of its liquidity crisis; the outcome of negotiations for support from its senior financial creditors; the economic viability of the business; and the reaction of the market to the company's financial trouble. Therefore, the key concerns in the furtherance of the rescue process in a world of uncertainty refer to the true value of the business, and the likelihood of the successful recovery 'turn[s] importantly upon

126 DG Baird and DS Bernstein, 'Absolute Priority, Valuation Uncertainty, and the Reorganization Bargain’ (2006) 115 Yale Law Journal 1930. 
evaluation of risk and a willingness to accept risk'.127 This dynamic nature makes the corporate rescue process even more complex and demanding. On the one hand, it needs to accommodate different stakeholders with dispersed interests bargaining with each other; on the other hand, it calls for trust among those participants as well as compromise, and possibly even necessary sacrifice from some stakeholders, in order to reach the successful rescue outcomes.

As we have seen, corporate rescue includes formal activities provided by legislation and informal activities. The key challenge to efficient negotiation in the informal rescue process is the creditor coordination problem, especially for companies with a large number of creditors and complex debt structures (often a mix of public, private and bank debt). These companies are likely to suffer from creditor holdout problems, in which a minority of claimholders refuse to accept a restructuring plan, and are better off restructuring under the less stringent voting requirements of statutory procedure. Formal rules for a collective rescue procedure, on the other hand, are designed to reduce information asymmetries and wasteful strategic behaviour and to promote cooperation in order to facilitate the achievement of the most efficient outcome. For this reason the automatic stay provision and the voting rules under a statutory rescue procedure are devised to overcome the holdout problems.

Formal rescue-oriented proceedings have their advantages in providing a forum for structured negotiations among competing and diverse interests to avoid the unnecessary collapse of businesses in the chaos of financial distress. Nevertheless, the role of insolvency law is primarily, although not merely, a response to the problem of collecting debts. The formal rules in this context impose considerable limits on departing from the pre-insolvency entitlements of claimholders and on how far they can go in response to the substantial obstacles caused by the inherent uncertainty in the progression of rescue work.

Pre-pack restructuring is a hybrid form of corporate rescue and it does present an innovative approach to overcome the holdout problem in informal workouts by providing a formal procedure to solidify the outcome of private negotiations. Yet pre-pack rescue also face challenges in capturing the going concern surplus in an uncertain state of corporate distress. In particular, how should the competing interests and various goals that underlie the insolvency system (e.g. fairness or justice and wealth creation) be prioritised when a trade-off is inevitable? This

127 JL Westbrook, 'The Control of Wealth in Bankruptcy' (2004) 82 Texas Law Review 795, 805. 
problem could be more acute in a pre-pack restructuring, where tradeoffs are often pre-determined and market-led, but not always in line with the statutory objectives of a particular insolvency law. These challenges are key to the successful use and completion of pre-pack arrangements and they are extensively discussed in subsequent chapters. 